\title{
SPLITSING DALAM PERSPEKTIF ASAS CONTANTE JUSTITIE \\ DAN ASAS NON SELF INCRIMINATION \\ (SPLITSING IN CONTANTE JUSTITIE AND NON-SELF INCRIMINATION PRINCIPLES PERSPECTIVE) \\ Oleh: Elwindhi Febrian \\ Fakultas Hukum Universitas Islam Indonesia (UII) Yogyakarta \\ Email: elwindidifebrian@gmail.com
}

\begin{abstract}
ABSTRAK
Penuntut Umum dalam membuat dakwaan suatu dugaan tindakan pidana yang dilakukan oleh lebih dari satu terdakwa acap kali melakukan pemisahan perkara atau sering disebut dengan splitsing, kemudian dengan berkas perkara yang terpisah para terdakwa saling bersaksi untuk satu sama lain. Praktek demikian mengakibatkan proses persidangan menjadi berbelit-belit sehingga bertentangan dengan asas contante justitie. Memunculkan saksi dari perkara splitsing juga beresiko melanggar hak asasi Terdakwa karena mereka harus bersaksi atas tindak pidana yang dituduhkan kepada dirinya sendiri sehingga beresiko memberikan keterangan yang memberatkan dirinya sendiri, hal tersebut bertentangan dengan asas non self-incrimination. Pasal 142 KUHAP mengatur mengenai pemisahan perkara, dan mengatur dengan jelas bagaimana perkara dapat dilakukan pemisahan perkara. Namun dalam prakteknya pemisahan perkara tidak sesuai dengan maksud dan tujuan dari KUHAP yang diciptakan untuk memberikan penghargaan yang besar terhadap hak asasi manusia, justru sebaliknya digunakan untuk melanggar hak asasi manusia.
\end{abstract}

Kata Kunci: Splitsing, Asas Contante Justitie, Asas Non Self-Incrimination.

\begin{abstract}
Splitting of indictment, known as splitsing, is often applied by the general prosecutor to accuse multi defendant indictment. With this separated indictment, the defendants are testifying one to another. Besides it leads convoluted trial court, this practice contradicts to contante justitie principle since attending a splitsing-witness might be risks to violate his / her own right as a defendant. Furthermore, his / her testimony might aggravates his position as a defendant and contradicts to a principle called self -incrimination principle. Article 142 Indonesian Criminal Procedure Code regulates splitsing as well as its requirements. However, in the empirical fact, the practice does not harmonize with the aim and the purpose of its code; what is created to award to human right, contrary used to violate human right itself.
\end{abstract}

Keywords: Splitsing, Contante Justitie Principle, Non Self-Incrimination Principle.

\section{A. Pendahuluan}

Hukum pidana sebagai aturan hukum

dari suatu negara yang berdaulat, berisi perbuatan yang dilarang atau perbuatan yang diperintahkan, disertai dengan sanksi pidana bagi yang melanggar atau yang tidak 
mematuhi, kapan dan dalam hal apa sanksi pidana itu dijatuhkan dan bagaimana pelaksanaan pidana tersebut yang pemberlakuan dipaksakan oleh negara. ${ }^{1}$ Eddy O.S Hiariej berpendapat bahwa hukum pidana merupakan hukum terakhir yang digunakan jika instrumen hukum lainnya tidak dapat digunakan atau tidak dapat berfungsi sebagaimana mestinya. ${ }^{2}$ Penjelasan tersebut menjelaskan selain hukum pidana materiil, hukum pidana formil merupakan bagian yang tidak terpisahkan dari hukum pidana.

Undang-Undang Republik Indonesia Nomor 8 Tahun 1981 tentang Hukum Acara Pidana atau sering disebut Kitab Undang-Undang Hukum Acara Pidana (KUHAP) merupakan pengaturan hukum formil (hukum acara pidana) di Indonesia. Penulis melihat KUHAP masih memiliki kekurangan-kekurangan untuk tercipta sistem peradilan pidana yang memberikan penghargaan besar terhadap Hak Asasi Manusia (HAM) atau sistem peradilan pidana dengan berprinsip pada due proces of law. Pengertian Due Process of Law adalah proses hukum yang benar atau adil yang merupakan prinsip Hukum Acara Pidana di Indonesia ${ }^{3}$, dalam hal ini seseorang yang diduga melakukan perbuatan pidana tetap mendapatkan perlakuan yang tidak terlanggar hak-hak asasinya.

Salah satu hal yang menarik untuk dikaji dan dianalisa dari KUHAP adalah pemisahan perkara (splitsing), penggabungan dan pemisahan perkara yang melekat kewenangannya kepada JPU (Jaksa Penuntut Umum) dalam memformulasikan dakwaan dan tuntutan. Penggabungan perkara diatur dalam pasal 141 KUHAP dan pemisahan perkara (splitsing) diatur dalam pasal 142 KUHAP.

Andi Hamzah menyatakan biasanya splitsing dilakukan dengan membuat berkas perkara baru dimana para tersangka saling menjadi saksi, sehingga untuk itu perlu dilakukan pemeriksaan baru, baik terhadap tersangka maupun saksi. ${ }^{4}$ Jika terdakwa lebih dari satu orang maka dilakukan pemisahan perkara yang kemudian para Terdakwa dijadikan saksi dan saling bersaksi untuk perbuatan pidana yang didakwakannya atau yang sering disebut

Eddy O.S Hiariej, Prinsip-Prinsip Hukum Pidana, (Yogyakarta, Cahaya Atma Pustaka, 2014),hlm. 13. Ibid, hlm. 27.

Dzulkifli Umar dan Usman Handoyo, Kamus Hukum, (Jakarta: Quantum Media Press, 2010), hlm.105

Andi Hamzah, Hukum Acara Pidana Indonesia (Jakarta: Sinar Grafiaka, 2013), hlm. 164. 
saksi mahkota. Saksi mahkota sebenarnya menunjukan pada terdakwa yang berstatus menjadi saksi dalam perkara terdakwa yang lain yang sama-sama melakukan yaitu dalam hal diadakan splitsing dalam pemeriksaannya. ${ }^{5}$

Menggunakan istilah saksi mahkota terhadap saksi dari perkara splitsing tersebut sebenarnya tidak tepat, Andi Hamzah menyatakan saksi mahkota (kroongetuige) adalah salah seorang Terdakwa (biasanya adalah yang paling ringan kesalahannya) dijadikan (dilantik) menjadi saksi, jadi seperti diberi mahkota, yang tidak akan dijadikan terdakwa lagi. ${ }^{6}$

Salah satu contoh kasus pemisahan perkara dalam satu perkara pidana adalah perkara pidana dalam Putusan PN Kota Agung No.58/Pid.B/2014 /PN.KOT yang diinformasikan oleh hukumonline.com, "splitsing dilakukan terhadap perkara dimana terdapat beberapa pelaku tindak pidana tetapi hanya satu tindak pidana yang dilakukan. Sebagai contoh kasus dapat kita lihat dalam Putusan Pengadilan Negeri Kota Agung No. 58/Pid.B/2014/PN.KOT, dimana terdakwa melakukan pencurian dengan Zulkarnain Bin Bakri (splitsing) dan Hendra Bangsawan Bin Akmal (splitsing) pada malam hari. Berkas perkara ketiga pelaku dipecah (splitsing) menjadi tiga". ${ }^{7}$

Praktek splitsing seperti demikian ternyata berbenturan dengan asas hukum yang ada, yaitu asas Contante Justitie (peradilan cepat, sederhana dan biaya ringan) dan asas non self-incrimination (asas hak untuk tidak memberikan keterangan yang memberatkan dirinya sendiri dalam proses peradilan pidana).

Splitsing yang dipaksakan memberikan kesan persidangan yang berbelit-belit dan tidak sederhana. Para Terdakwa harus menjalani pemeriksaan sidang sebagai Terdakwa dan sebagai saksi. Pada prinsipnya suatu dugaan tindak pidana yang dilakukan oleh lebih dari satu Tersangka / Terdakwa Jaksa Penuntut Umum dapat menggabungkan perkara dalam satu dakwaan sehingga persidangan akan lebih cepat, sederhana dan biaya ringan.

Terdakwa yang dijadikan saksi dalam perkara splitsing saat bersaksi dengan sadar

\footnotetext{
Suryono Sutarto, Hukum Acara Pidana Jilid 1, (Semarang: Badan Penerbit Undip, 1991), hlm 53.

Andi Hamzah, op.cit, hlm.166.

Sofia Hasanah, Pemisaha Berkas Perkara Pidana (Splitsing), http://www.hukumonline.com/klinik/detail/lt588275023a37c/pemisahan-berkas-perkara-pidanaisplitsing-i, diakses pada 23 Septemeber Pukul 16.00 WIB.
} 
setiap ucapannya dapat mempengaruhi hasil akhir putusan pengadilan, maka kesaksiannya berpotensi untuk tidak jujur dan tidak sesuai fakta bahkan bisa memperberat dirinya sendiri karena bagaimanapun juga dia sedang bersaksi atas perbuatan yang dilakukannya sendiri.

Penerapan splitsing ini menarik untuk dilakukan penelitian karena dalam prakteknya memunculkan proses persidangan yang tidak efisien dan efektif bahkan berpotensi melanggar hak asasi Tersangka / Terdakwa secara terangnya berpotensi melanggar asas universal yaitu asas contante justitie dan asas non selfincrimination. Beberapa penelitian sudah membahas mengenai permasalahan ini.

Pertama, Ignatius A. Tiolong, Veibe V. Sumilat, Harold Anis berjudul Wewenang Pemecahan Perkara (splitsing) Oleh Penuntut Umum Menurut Pasal 142 Undang-Undang Nomor 8 Tahun $1981,{ }^{8}$ Hasil dari penelitiannya adalah syarat untuk dilakukannya pemecahan perkara (splitsing) oleh Penuntut Umum berdasarkan Pasal 142 KUHAP yaitu: 1) Penuntut Umum menerima 1 (satu) berkas perkara; 2) Satu berkas itu memuat beberapoa tindak pidana; 3) Beberapa tindak pidana itu dilakukan oleh beberapa orang tersangak; 4) Yang tidak termasuk dalam pasal 141 KUHAP pemecahan perkara yang mengakibatkan tersangka pada perkara yang satu menjadi saksi dalam perkara yang lain, bukan pemecahan perkara dalam arti Pasal 142 KUHAP, karena pemecahan perkara ini tidak dapat dilakukan oleh Penuntut Umum sendiri melainkan harus dilakukan melalui prapenuntutan yaitu dikembalikan kepada penyidik. Ditinjau dari sudut perlindungan Hak Asasi Manusia tersangka / terdakwa, terdapat dua asas yang tidak membenarkan dilakukannya pemecahan perkara (splitsing), yaitu: a. asas dalam Pasal 166 KUHP, yaitu orang tidak dapat diwajibkan memberatkan dirinya sendiri, khususnya untuk melakukan perbuatan yang yang mungkin mendatangkan bahaya penuntutan pidana bagi dirinya sendiri; dan b. Pasal 14 ayat (3) huruf (g) The International Covenant on Civil and Political Rights, yang menentukan bahwa seseorang yang dituntut pidana setidaktidaknya

8 Ignatius A. Tiolong, Veibe V. Sumilat, Harold Anis, Wewenang Pemecahan Perkara (splitsing) Oleh Penuntut Umum Menurut Pasal 142 Undang-Undang Nomor 8 Tahun 1981, Lex Crimen Vol. VII/No. 6/Ags/2018: 152. 
(minimum) berhak sepenuhnya atas jaminan untuk tidak dipaksa bersaksi melawan diri sendiri atau untuk mengaku bersalah. Tetapi praktik sekarang, berdasarkan Putusan Mahkamah Agung No. 2437 K/Pid.Sus/2011 dan Surat Edaran Kejaksaan Agung Republik Indonesia No. B69/E/02/1997, membolehkan sesama tersangka menjadi saksi yang memberatkan bagi tersangka lain sebagai saksi mahkota. ${ }^{9}$

Kedua, Igusti Ayu Aditya Wati bekara berjudul Pemecahan Perkara (Splitsing) Dalam Pra Penuntutan, hasil penelitiannya adalah pemecahan perkara merupakan wewenang dari Jaksa Penuntut Umum. Pemecahan perkara dilakukan atas petunjuk dari Jaksa Penuntut Umum yang mana petunjuk tersebut dapat diberikan oleh Jaksa Penuntut Umum pada saat penyerahan berkas pada tahap pertama ataupun sebelum berkas tersebut diserahkan secara resmi kepada Jaksa Penuntut Umum. Dalam melakukan pemecahan perkara, Jaksa Penuntut Umum mempunyai pertimbangan yaitu perbuatan yang dilakukan tanpa saksi dan kurang didukung alat bukti sah lainnya, pelaku tindak pidana terdiri dari beberapa orang dan memudahkan Jaksa Penuntut Umum dalam menyusun tuntutan. ${ }^{10}$

Mencermati dua penelitian terdahulu di atas, terdapat perbedaan dengan penelitian yang penulis buat baik dari substansi, isi, maupun topiknya. Unsur baru dalam penelitian ini terletak pada fokus analisis praktek splitsing dilihat dari perspekstif asas contante justitie dan asas non self-incrimination.

Berdasarkan latar belakang masalah di atas, penulis mendapatkan 2 (dua) rumusan masalah antara lain :

(1) Apakah splitsing bertentangan dengan asas contante Justitie?

(2) Apakah splitsing bertentangan dengan asas non self-incrimination?

\section{B. Metode Penelitian}

Penelitian ini menggunakan metode Yuridis Normatif, Soerjono Soekanto mengemukakan bahwa penelitian hukum normatif yaitu penelitian yang

9 Ibid, hlm. 157.

10 Igusti Ayu Aditya Wati bekara berjudul, Pemecahan Perkara (Splitsing) Dalam Pra Penuntutan, (Bagian Hukum Administrasi Negara Fakultas Hukum Universitas Udayana), hlm. 5 https://ojs.unud.ac.id/index.php/Kerthanegara/article/view/19000 ,diakses 5 November 2019 
menggunakan norma-norma yang ada dalam perundang-undangan. ${ }^{11}$

\section{Pendekatan yang dipakai dalam} penelitian ini adalah metode pendekatan perundang-undangan, peraturan perundang-undangan adalah peraturan tertulis yang memuat norma hukum yang mengikat secara umum dan dibentuk atau ditetapkan oleh lembaga negara atau pejabat yang berwenang melalui prosedur yang ditetapkan dalam peraturan perundang-undangan. ${ }^{12}$

Pendekatan berikutnya menggunakan pendekatan konseptual, Peneliti merujuk prinsip-prinsip hukum. Prinsip-prinsip ini dapat ditemukan dalam pandanganpandangan sarjana ataupun doktrin-doktrin umum. Meskipun tidak secara eksplisit, konsep hukum dapat ditemukan di dalam unsang-undang. Hanya saja dalam mengidentifikasi prinsip tersebut peneliti terlebih dahulu memahami konsep tersebut melalui pandangan-pandangan dan doktrin yang ada. ${ }^{13}$

Teknik pengumpulan data menggunakan studi kepustakaan merupakan metode tunggal yang dipergunakan dalam penelitian normatif. Dan bahan hukumnya bersumber pada Buku, Kertas konferensi, laporan penelitian, laporan teknis, majalah, disertasi dan tesis, paten. ${ }^{14}$ Untuk memperoleh data dilakukan dengan menggunakan studi dokumen. ${ }^{15}$

Analisis data yang diakukan oleh peneliti menggunakan pendekatan kualitatif. Analisis kualitatif juga dipergunakan dalam penelitian hukum normatif. ${ }^{16}$ Analisis bahan-bahan yang telah dikumpulkan tentu saja harus dilakukan menurut cara-cara analisis atau penafsiran (interpretasi) hukum yang dikenal, seperti penafsiran auntentik. ${ }^{17}$

11 Soerjono Soekanto dan Sri Mamudji, Penelitian Hukum Normatif Tinjauan Singkatan, Cetakan Ketujuh (Jakarta: PT. Raja Grafindo Persada, 2003), HIm 11.

12 Ibid., hlm 137.

13 Peter Mahmud Marzuki, Peneitian Hukum Edisi Revisi, Cetakan kedua belas ( Jakarta:Pranadamedia Group, 2016), hlm. 178

14 Suratman dan Philips Dillah, Metode Penelitian Hukum,Cetakan Ketiga (Bandung: ALFABETA,2015), hlm. 123

15 Burhan Ashofa, Metode Penelitian Hukum, Cetakan pertama (Jakarta: PT Rineka Cipta, 1996), hlm.152

16 Suratman dan Philips Dillah ... op. cit, hlm. 145.

17 Sunaryati Hartono, Penelitian Hukum di Indonesia pada Akhir Abad ke-20, Cetakan pertama (Bandung: Penerbit alumni, 1994), hlm. 152 


\section{Pembahasan}

1. Asas Contante Justitie (Asas Peradilan Cepat, Sederhana, dan Biaya Ringan).

Asas Contante Justitie atau yang sering dikenal asas peradilan cepat, sederhana, dan biaya ringan merupakan salah satu asas hukum yang dijadikan dasar dalam pelaksanaan hukum acara di Indonesia, yang asas tersebut kemudian diimplementasikan dalam sistem peradilan pidana di Indonesia.

Undang-Undang Nomor 48 Tahun 2009 tentang Kekuasaan Kehakiman, tepatnya tertuang dalam pasal 4 Ayat (2) yang berbunyi "Pengadilan membantu pencari keadilan dan berusaha mengatasi segala hambatan dan rintangan untuk dapat tercapainya peradilan yang sederhana, cepat, dan biaya ringan". Yang dalam penjelasan atas pasal tersebut sebagai berikut, "Yang dimaksud dengan "sederhana" adalah pemeriksaan dan penyelesaian perkara dilakukan dengan cara efesien dan efektif. Yang dimaksud dengan "biaya ringan" adalah biaya perkara yang dapat dijangkau oleh masyarakat. Namun demikian, asas sederhana, cepat, dan biaya ringan dalam pemeriksaan dan penyelesaian perkara di pengadilan tidak mengesampingkan ketelitian dan kecermatan dalam mencari kebenaran dan keadilan.

Kitab Undang-Undang Hukum Acara Pidana (KUHAP) atau Undang-Undang Republik Indonesia Nomor 8 Tahun 1981 sebagai dasar penegak hukum baik penyidik, penuntut umum, hakim dalam melaksanakan penegakan hukum. KUHAP sendiri dalam substansi pasal-pasalnya sudah mengambil asas Contante Justitie, misalnya dengan memberikan kata segera maupun pemberian batas waktu dalam menangani perkara pada setiap prosesnya.

M. Hatta Ali menyatakan peradilan sebagai suatu sistem dengan mempunyai mekanisme yang bergerak menuju kearah pencapaian misi dari hakikat keberadaan peradilan. Sistem peradilan menuntut adanya visi yang jelas agar aktivitas atau pelaksanaan peran peradilan berproses secara efektif dan efisien. Persepsi masyarakat terhadap Pengadilan dan peradilan yang baik adalah kalau proses perkara pengadilan yang dilalui mulai dari pendaftaran sampai keluar 
putusan tidak berbelit-belit, efisien dan biaya ringan. ${ }^{18}$

Menurut Lilik Riyadi, secara konkret apabila dijabarkan bahwa dengan dilakukan peradilan secara sederhana, cepat, dan biaya ringan dimaksudkan supaya Terdakwa (misalnya dalam perkara pidana) tidak diperlakukan dan diperiksa sampai berlarut-larut, dan terdakwa memperoleh kepastian prosedural hukum serta proses administrasi biaya perkara yang ringan dan tidak terlalu membebaninya. Terhadap penerapan asas ini dalam praktik peradilan dapatlah diberikan nuansa bahwa peradilan cepat dan sederhana tampak dengan adanya pembatasan waktu penanganan perkara baik perdata maupun pidana pada tingkat judex faktie di Pengadilan Tingkat Pertama dan Pengadilan Tingkat Banding. ${ }^{19}$

\section{Prinsip Non Self-Incrimination}

Asas Non Self-Incrimination secara garis besar artinya Terdakwa diberikan hak untuk tidak memberikan suatu keterangan yang dapat memberatkan dirinya sendiri dalam proses peradilan pidana, asas tersebut adalah suatu prinsip Universal yang juga diterapkan di negara Republik Indonesia, dalam Article 14 paragraph 3 (g) International Covenant on Civil and Political Rights, disingkat ICCPR atau dalam bahasa Indonesia Kovenan Internasional HakHak Sipil Dan Politik dimana Indonesia juga turut menandatangani perjanjian tersebut, yang berbunyi Not to be compelled to testify against himself or to confess guilt (Tidak dipaksa untuk bersaksi melawan dirinya sendiri atau mengakui kesalahan) atau dapat diartikan kurang lebih "Untuk tidak dipaksa memberikan kesaksian yang memberatkan dirinya, atau dipaksa mengaku bersalah".

KUHAP juga mengakomodir prinsip non self-incrimination namun tidak secara eksplisit, dijelaskan pada Pasal 52 KUHAP: "Dalam pemeriksaan pada tingkat penyidikan dan pengadilan, tersangka atau terdakwa berhak memberikan keterangan secara bebas kepada penyidik atau hakim". Kata

18 M. Hatta Ali, Peradilan Sederhana cepat \&Biaya Ringan Menuju Keadlian Restoratif (Bandung: PT. Alumni, 2012), hlm. 229.

19 Lilik Mulyadi, Hukum Acara Pidana : Normatif, Teoritis, Praktik, dan Permasalahannya (Bandung: PT. Alumni, 2007), hlm.14. 
memberikan keterangan secara bebas tersebut mengartikan bahwa tersangka atau terdakwa bebas dalam memberikan keterangan tetapi kata memberikan keterangan secara bebas belum mengakomodir tersangka atau terdakwa diberikan hak diam. Kemudian 5 alat bukti yang diatur pada pasal 184 KUHAP adalah sebagai berikut :
a. Keterangan saksi
b. Keterangan ahli
c. Surat
d. Petunjuk
e. Keterangan Terdakwa

Keterangan terdakwa sebagai salah satu alat bukti tetapi ditempatkan pada urutan terakhir, hal tersebut menunjukan bahwa keterangan terdakwa memiliki kekuatan pembuktian yang paling lemah sehingga menuntut penegak hukum untuk menghadirkan alat bukti yang lebih kuat kekuatan pembuktiannya. Bahkan KUHAP mengatur apabila Terdakwa tidak berkenan memberikan jawaban maka tidak menghalangi jalannya persidangan hal tersebut diatur dalam Pasal 175 KUHAP yang berbunyi "Jika terdakwa tidak mau menjawab atau menolak untuk menjawab, pertanyaan yang diajukan kepadanya, hakim ketua sidang menganjurkan untuk menjawab dan setelah itu pemeriksaan dilanjutkan".

Kitab Undang-Undang Hukum Acara Pidana yang secara substansial menganut nilai-nilai yang dianut dalam sistem akusatur dan mengenyampingkan (walaupun belum sepenuhnya) nilai-nilai yang dianut sistem inkusitur. ${ }^{20}$ Tersangka atau terdakwa dalam sistem ini dipandang sebagai subjek sehingga kedudukan mereka sederajat dengan pemeriksa. Mulailah dikenal istilah the right to remain silent yang artinya hak untuk tidak menjawab pertanyaan atau hak untuk diam.

Larangan terhadap kriminalisasi diri yang merupakan suatu larangan terhadap pemaksaan untuk menjadi saksi atau tersangka yang membahayakan atau membawa konsekuensi hukum terhadap diri saksi tersangka memiliki justifikasi yang cukup valid, yakni penghormatan

20 Romli Atmasasmita, Sistem Peradilan Pidana Kontemporer (Jakarta: Kencana Prenada Media Group, 2010), hlm 53. 
terhadap harkat dan martabat saksi atau tersangka itu sendiri. ${ }^{21}$ Semakin demokratis suatu negara maka akan semakin kuat berlakunya privilege untuk diam sehingga tidak terjadi selfincrimantion dalam proses penegakan hukum pidana. ${ }^{22}$

3. Penggabungan dan Pemisahan

\section{Perkara Pidana dalam KUHAP}

Penggabungan perkara dalam satu surat dakwaan diatur dalam Pasal 141 KUHAP yang berbunyi, "Penuntut umum dapat melakukan penggabungan perkara dan membuatnya dalam satu surat dakwaan, apabila pada waktu yang sama atau hampir bersamaan ia menerima beberapa berkas perkara dalam hal:

a. Beberapa tindak pidana yang dilakukan oleh seorang yang sama dan kepentingan pemeriksaan tidak menjadikan halangan terhadap penggabungannya;

b. Beberapa tindak pidana yang bersangkut-paut satu dengan yang lain; c. Beberapa tindak pidana yang tidak bersangkut-paut satu dengan yang lain, akan tetapi yang satu dengan yang lain itu ada hubungannya, yang dalam hal ini penggabungan tersebut perlu bagi kepentingan pemeriksaan."

\section{Penjelasan atas pasal 141 KUHAP :}

Yang dimaksud dengan "tindak pidana dianggap mempunyai sangkut paut satu dengan yang lain," apabila tindak pidana tersebut dilakukan :

1. Oleh lebih dari seorang / yang bekerjasama dan dilakukan pada saat yang bersamaan;

2. Oleh lebih dari seorang pada saat dan tempat yang berbeda, akan tetapi merupakan pelaksanaan dari permufakatan jahat yang dibuat oleh mereka sebelumnya;

3. Oleh seorang atau lebih dengan maksud mendapatkan alat yang akan dipergunakan untuk melakukan tindak pidana lain atau menghindarkan diri dari pemidanaan karena tindak pidana lain.

21 Munir Fuady, Hak Asasi Tersangka Pidana (Jakarta: Prenada Media Group, 2015), hlm. 58.

22 Ibid, hlm.58. 
Bunyi pasal dan penjelasan pasal di atas penggabungan perkara dalam satu surat dakwaan dapat dilakukan dan dianjurkan oleh undang undang dengan syarat memenuhi kriteria yang dijelaskan dalam Pasal 141 KUHAP tersebut.

Penuntut Umum juga memiliki kewenangan untuk melakukan pemisahan perkara atau splitsing yang diatur dalam Pasal 142 KUHAP dengan bunyi, "Dalam hal penuntut umum menerima satu berkas perkara yang memuat beberapa tindak pidana yang dilakukan oleh beberapa orang tersangka yang tidak termasuk dalam ketentuan Pasal 141, penuntut umum dapat melakukan penuntutan terhadap masing-masing terdakwa secara terpisah."

Bunyi Pasal 142 KUHAP sudah jelas mengatur kewenangan Penuntut Umum untuk melakukan pemisahan perkara dengan ketentuan perkara tindak pidana yang dilakukan oleh beberapa orang itu tidak termasuk dalam ketentuan Pasal 141 KUHAP.
4. Terdakwa Menjadi Saksi atas dakwaan

\section{Splitsing}

Andi Hamzah menyatakan biasanya splitsing dilakukan dengan membuat berkas perkara baru dimana para tersangka saling menjadi saksi, sehingga untuk itu perlu dilakukan pemeriksaan baru, baik terhadap tersangka maupun saksi. ${ }^{23}$ Mungkin kalau tidak ada saksi, sedangkan ada beberapa orang tersangka hal demikian benar, artinya tersangka bergantian menjadi saksi. Tetapi hal demikiaan sesungguhnya dapat menimbulkan kemungkinan orang dipaksa melakukan sumpah palsu, karena secara logis para saksi akan berbohong, tidak akan memberatkan tersangka (terdakwa), karena pada gilirannya ia sendiri akan menjadi tersangka (terdakwa). ${ }^{24}$

KUHAP dalam pasal 1 angka 26, menjelaskan saksi adalah orang yang dapat memberikan keterangan guna kepentingan penyidikan, "penuntutan dan peradilan tentang suatu"perkara pidana yang ia dengar sendiri, ia lihat

23 Andi Hamzah, Hukum Acara Pidana Indonesia (Jakarta: Sinar Grafiaka, 2013), hlm. 164.

24 Ibid, hlm. 165 
sendiri dan ia alami sendiri. Saksi merupakan salah satu dari 5 (lima) alat bukti yang diatur dalam pasal 184 KUHAP dan memiliki kekuatan pembuktian paling kuat karena ditempatkan pada urutan teratas dalam urutan alat bukti.

Tersangka atau Terdakwa sendiri tidak dibebani kewajiban pembuktian, hal tersebut diatur dalam Pasal 66 KUHAP, "Tersangka atau terdakwa tidak dibebani kewajiban pembuktian". Berdasarkan teori pembuktian dalam hukum acara pidana, keterangan yang diberikan oleh saksi di persidangan dipandang sebagai alat bukti yang penting dan utama. ${ }^{25}$ Hal tersebut memiliki konsekuensi terhadap tugas penegak hukum untuk semaksimal mungkin dapat menghadirkan saksi terhadap suatu tindak pidana.

Terdakwa tidak dapat dijadikan saksi karena KUHAP tidak mengatur kesaksian terdakwa menjadi salah satu alat bukti, Pemisahan perkara (splitsing) dalam prakteknya bertujuan agar para Terdakwa muncul sebagai saksi atas Terdakwa lainnya atau sering

disebut sebagai saksi mahkota. KUHAP tidak mendefinisikan secara jelas apa itu saksi mahkota.

Ditemukan dalam Putusan MA No. 2437 K/Pid.Sus/2011, saksi mahkota didefinisikan sebagai berikut: "Walaupun tidak diberikan suatu definisi otentik dalam KUHAP mengenai saksi mahkota didefinisikan sebagai saksi yang berasal atau diambil dari salah seorang Tersangka atau Terdakwa lainnya yang bersama-sama melakukan perbuatan pidana, dan dalam hal mana kepada Saksi tersebut diberikan mahkota.

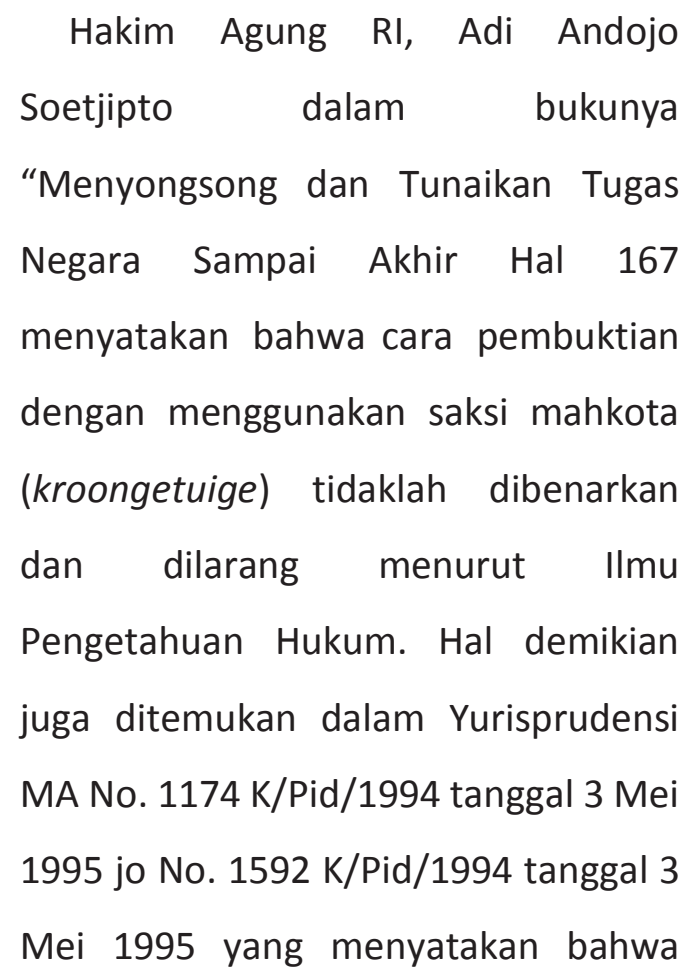

25 M. Yahya Harahap, Pembahasan Permasalahan dan Penerapan KUHAP, Pemeriksaan Sidang Pengadilan, Banding, Kasasi dan Peninjauan Kembali, Edisi II (Sinar Grafika, Jakarta, 2000), hlm. 265. 
pemeriksaan terhadap saksi mahkota sebaiknya tidak dilakukan karena hal itu bertentangan dengan hukum acara pidana yang menjunjung tinggi prinsipprinsip hak asasi manusia. ${ }^{26}$

Menempatkan para terdakwa untuk saling menjadi saksi atas suatu dugaan tindak pidana memang menjadi hal yang rancu, disuatu sisi mereka tidak diberikan beban pembuktian atas dugaan tindak pidana yang meraka lakukan tetapi akibat dari splitsing mereka dipaksakan menjadi saksi atas dugaan tindak pidana yang mereka lakukan. Disisi lain saat Terdakwa diposisikan menjadi Saksi yang wajib diambil sumpahnya sebelum memberikan kesaksian di muka persidangan, maka mereka dalam situasi dipaksakan bersumpah untuk menyatakan dirinya melakukan tindak pidana.

\section{Tinjauan Splitsing Bertentangan} dengan Asas Contante Justitie

Jika dilihat dari asas contante justitie, kebijakan dari penuntut umum untuk melakukan splitsing yang tujuannya hanya menjadikan para terdakwa sebagai saksi satu sama lain hanya akan mempersulit dan memperlambat proses persidangan, dimana orang harus menjadi saksi sekaligus terdakwa, praktek semacam itu menimbulkan sesuatu yang berbelit-belit sehingga wujud peradilan cepat, sederhana dan biaya ringan tidak terpenuhi. Penggabungan perkara adalah perwujudan dari peradilan yang cepat, sederhana dan biaya ringan, apabila suatu dugaan tindak pidana dapat dilakukan penggabungan tidak perlu bagi penuntut umum untuk melakukan pemisahan perkara (splitsing). Proses yang berbelit-belit pastinya akan membuat biaya yang lebih tinggi bagi seluruh pihak yang terlibat dalam perkara.

Pasal 141 KUHAP yang berbunyi, "Penuntut umum dapat melakukan penggabungan perkara dan membuatnya dalam satu surat dakwaan, apabila pada waktu yang sama atau hampir bersamaan ia

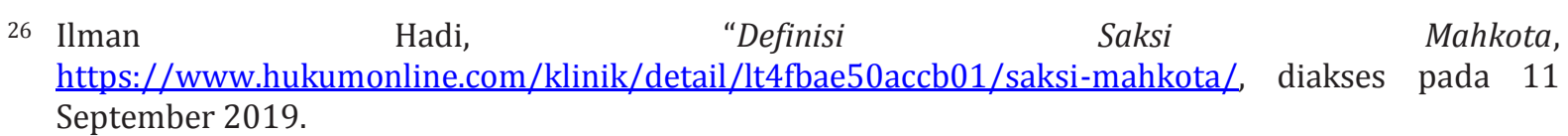


menerima beberapa berkas perkara dalam hal:

a. Beberapa tindak pidana yang dilakukan oleh seorang yang sama dan kepentingan pemeriksaan tidak menjadikan halangan terhadap penggabungannya;

b. Beberapa tindak pidana yang bersangkut-paut satu dengan yang lain;

c. Beberapa tindak pidana yang tidak bersangkut-paut satu dengan yang lain, akan tetapi yang satu dengan yang lain itu ada hubungannya, yang dalam hal ini penggabungan tersebut perlu bagi kepentingan pemeriksaan."

\section{Penjelasan atas pasal 141 KUHAP :}

Yang dimaksud dengan "tindak pidana dianggap mempunyai sangkut paut satu dengan yang lain," apabila tindak pidana tersebut dilakukan :

1. Oleh lebih dari seorang / yang bekerjasama dan dilakukan pada saat yang bersamaan;

2. Oleh lebih dari seorang pada saat dan tempat yang berbeda, akan tetapi merupakan pelaksanaan dari permufakatan jahat yang dibuat oleh mereka sebelumnya;
3. Oleh seorang atau lebih dengan maksud mendapatkan alat yang akan dipergunakan untuk melakukan tindak pidana lain atau menghindarkan diri dari pemidanaan karena tindak pidana lain.

Pasal 142 KUHAP dengan bunyi, "Dalam hal penuntut umum menerima satu berkas perkara yang memuat beberapa tindak pidana yang dilakukan oleh beberapa orang tersangka yang tidak termasuk dalam ketentuan Pasal 141, penuntut umum dapat melakukan penuntutan terhadap masing-masing terdakwa secara terpisah."

Maksud dari penggabungan perkara yang diatur dalam pasal 141 KUHAP dapat dipahami Jaksa Penuntut Umum dianjurkan melakukan penggabungan perkara terhadap suatu delik pidana yang dilakukan oleh lebih dari satu orang yang memiliki sangkut paut satu dengan lainnya. Suatu penggabungan perkara dapat dipahami juga KUHAP menginginkan proses peradilan pidana dapat dilakukan dengan cepat, sederhana dan biaya ringan.

Terkait dengan kewenangan Jaksa Penuntut Umum dalam melakukan 
splitsing yang diatur dalam pasal 142, dapat dipahami apabila dalam suatu berkas perkara terdapat beberapa tindak pidana degan syarat tidak bertentangan dengan pasal 141 maka splitsing itu dapat dilakukan untuk tujuan mempermudah Jaksa Penuntut Umum melakukan penuntutan. Pasal 142 juga dapat dipahami pemisahan perkara yang seperti demikian bertujuan untuk menyelenggarakan proses peradilan pidana yang cepat, sederhana dan biaya ringan. Karena jika beberapa perbuatan pidana yang dijadikan dalam satu surat dakwaan juga akan mempersulit pemeriksaan di Persidangan.

Penuntut Umum memang memiliki kewenangan penuh dalam membuat dakwaan dan tuntutan yang melekat asas dominus litis, tetapi jika pemisahan perkara itu dilakukan tidak sesuai dengan ketentuan pada KUHAP yang diatur dalam Pasal 142 KUHAP maka sudah jelas tindakan tersebut bertentangan dengan asas contante justitie.

6. Tinjauan Splitsing Bertentangan Asas Non Self-Incrimination
Pemisahan perkara (splitsing) terhadap suatu tindak pidana yang dilakukan lebih dari satu orang yang kemudian memunculkan saksi dari para pelaku tindak pidana itu sendiri atau sering disebut dengan saksi mahkota dalam proses persidangan adalah suatu hal yang memaksakan suatu proses sistem peradilan pidana yang sebenarnya hal tersebut bukan sesuatu yang wajib untuk dilakukan karena dalam Pasal 184 KUHAP sudah mengatur jenis-jenis alat bukti yang sah dalam perkara pidana.

Praktek yang ada pada peradilan pidana di Indonesia menempatkan para Terdakwa menjadi saksi karena adanya pemisahan perkara atau splitsing jauh dari tujuan makna saksi mahkota, melainkan bertujuan untuk menciptakan saksi dari suatu tindak pidana dari para pelaku yang sama saja para Terdakwa diberikan beban pembuktian.

Definisi saksi mahkota disamakan dengan saksi yang dipaksakan karena adanya pemisahan perkara, padahal keduanya memiliki maksud dan tujuan yang berbeda. Landasan hukum bagi penegak hukum dalam menjadikan 
terdakwa menjadi saksi terdakwa lain adalah Surat Edaran Kejaksaan Agung Republik Indonesia No. B-69/E/02/ 1997 perihal Hukum Pembuktian Dalam Perkara Pidana yang antara lain menyebutkan: Bahwa Yurisprudensi yang diikuti selama ini masih mengakui saksi Mahkota sebagai alat bukti.

Putusan Mahkamah Agung Nomor 1986K/Pid/1 989 tanggal 2 Maret 1990 menyatakan bahwa Jaksa Penuntut Umum diperbolehkan oleh undangundang mengajukan teman terdakwa yang ikut serta melakukan perbuatan pidana tersebut sebagai saksi di persidangan, dengan syarat bahwa saksi ini dalam kedudukannya sebagai terdakwa, tidak termasuk dalam berkas perkara yang diberikan kesaksian.

Putusan Mahkamah Agung Nomor 1986 K/Pid/1989 tanggal 21 Maret 1990 dijelaskan Mahkamah Agung tidak melarang apabila jaksa penuntut umum mengajukan saksi mahkota di persidangan dengan syarat bahwa saksi ini dalam kedudukannya sebagai terdakwa tidak termasuk dalam satu berkas perkara dengan terdakwa yang diberikan kesaksian.
Sebenarnya menamakan saksi yang demikian tidak tepat disebut dengan saksi mahkota, Andi Hamzah menyatakan saksi mahkota (kroongetuige) adalah salah seorang Terdakwa (biasanya adalah yang paling ringan kesalahannya) dijadikan (dilantik) menjadi saksi, jadi seperti diberi mahkota, yang tidak akan dijadikan terdakwa lagi. ${ }^{27}$

Fungsi saksi mahkota jelas peruntukannya, yaitu salah satu terdakwa membantu penegak hukum dalam mencari kebenaraan materiil suatu tindak pidana kemudian dia diberikan suatu penghargaan yang menguntungkan bagi Terdakwa yang dijadikan saksi mahkota. Saksi mahkota perlu dilindungi keberadaannya, tetapi tidak semua tersangka atau terdakwa bisa dijadikan saksi mahkota dengan seenaknya. Perlu adanya syarat dan ketentuan seorang tersangka atau terdakwa dijadikan saksi, setidaknya memenuhi syarat dan ketentuan sebagai berikut :

1. Yang bersangkutan (tersangka/ terdakwa) bukan pelaku utama; 
2. Yang bersangkutan (tersangka/ terdakwa) berkomitmen dengan iktikad baik akan membantu proses pemeriksaan pidana;

3. Yang bersangkuatan (tersangka/ terdakwa) berprilaku baik dan kooperatif;

4. Yang bersangkutan (tersangka/ terdakwa) dilindungi keselamatan dan keamanannya;

5. Yang bersangkutan (tersangka/ terdakwa) diberikan reward ketika menjadi saksi mahkota yang baik dan keterangannya benar, misal dikurangi hukumannya bahkan dapat dibebaskan dari sanksi pidana atau mengganti hukuman non penal.

Sitti Nuhayati Syamsuningsih dalam jurnalnya menyatakan bahwa seringkali keterangan terdakwa dalam kapasitasnya sebagai saksi mahkota yang terikat oleh sumpah digunakan sebagai dasar alasan untuk membuktikan kesalahan terdakwa dalam perkaranya sendiri apabila terdakwa berbohong. Hal ini tentunya bertentangan dan melanggar asas non self-incrimination. ${ }^{28}$

Terdakwa dipaksa untuk menjadi saksi untuk terdakwa lainnya yang ia sendiri terlibat dalam dugaan tindak pidana, maka beresiko adanya kesaksian palsu karena mereka akan memberikan keterangan yang menguntungkan menurut para saksi atau terdakwa. Hal demikian menjadikan kebeneran materiil menjadi tidak terbukti dengan sempurna. Lain halnya jika saksi mengatakan sejujurnya apa yang sebenarnya terjadi karena dia bersaksi dibawah sumpah, karena Terdakwa mengetahui jika berbohong dalam memberikan kesaksian akan mendapatkan sanksi pidana penjara dengan ancaman hukuman paling lama 9 (sembilan) tahun yang diatur dalam pasal 242 Kitab Undang-Undang Hukum Pidana (KUHP). Jelas hal itu melanggar Hak Asasi Manusia (HAM), asas Non Self Incrimination mengajak kepada penegak hukum untuk tidak menjadikan tersangka atau terdakwa sebagai objek dari penegakan hukum

28 Sitti Nurhayati Syamsuningsih, Perlindungan Hukum Terhadap Saksi Mahkota Dalam Perkara Tindak Pidana Korupsi, e Jurnal Katalogis, Volume 4 Nomor 7, 2016, hlm. 10. 
pidana melainkan sebagai subjek yang setara dengan pemeriksa perkara, tidak untuk dipaksa mengakui tindak pidana yang dilakukan yang bertujuan untuk membuktikan bahwa tersangka atau terdakwa benar melakukan tindak pidana.

Disebutkan dalam pasal 165 KUHP; apabila pemberitahuan itu mungkin mendatangkan bahaya penuntutan terhadap :

- Orang itu sendiri; atau,

- Seorang keluarganya sedarah atau semenda dalam garis lurus atau garis menyimpang derajat kedua atau ketiga; atau,

- Suami / isteri atau bekas suami / isterinya.

Dengan demikian, dalam Pasal 166 KUHP ini terkandung asas bahwa orang tidak dapat diwajibkan memberatkan diri sendiri (non self-incrimination), khususnya untuk melakukan perbuatan yang yang mungkin mendatangkan bahaya penuntutan pidana bagi dirinya sendiri. Dilihat dari sudut asas ini, tidak selayaknya apabila terdakwa di suatu perkara menjadi saksi di perkara lain, sedangkan kedua perkara itu saling terkait erat satu dengan yang lainnya, sebab dalam hal ini kesaksiannya secara tidak langsung merupakan pengakuanpengakuan tentang perannya dalam suatu tindak pidana. ${ }^{29}$

Article 14 paragraph 3 (g) International Covenant on Civil and Political Rights, disingkat ICCPR atau dalam bahasa Indonesia Kovenan Internasional Hak-Hak Sipil Dan Politik yang berbunyi Not to be compelled to testify against himself or to confess guilt (Tidak dipaksa untuk bersaksi melawan dirinya sendiri atau mengakui kesalahan) atau dapat diartikan kurang lebih "Untuk tidak dipaksa memberikan kesaksian yang memberatkan dirinya, atau dipaksa mengaku bersalah". Jelas bahwa konvensi tersebut sudah dirativikasi dan disahkan oleh Negara Indonesia yang kemudian menjadi Undang-Undang Republik Indonesia Nomor 12 Tahun 2005 Tentang Pengesahan International Covenant On Civil And Political Rights (Kovenan Internasional Tentang Hak-Hak Sipil Dan Politik).

29 Ignatius A. Tiolong, Veibe V. Sumilat, , Harold Anis... Op.cit, hlm. 155. 
Kitab Undang-Undang Hukum Acara Pidana (KUHAP) telah secara jelas dan tegas mewujudkan falsafah Pancasila ke dalam pasal-pasalnya, Pasal 197 ayat (1) huruf a menjelaskan surat putusan pemidanaan harus terdapat kepala putusan yang dituliskan "DEMI KEADILAN BERDASARKAN KETUHANAN YANG MAHA ESA". Dapat diartikan putusan tersebut haruslah mendekati rasa keadilan yang tentunya dilaksanakan sesuai dengan peraturan perundang-undangan yang berlaku dan pertanggungjawaban putusan tersebut kepada Tuhan Yang Maha Esa.

Bahwa KUHAP dibuat dengan semangat menjunjung tinggi hak asasi manusia, hal tersebut dapat dilihat dari bunyi bab menimbang sub a UndangUndang Republik Indonesia Nomor 8 Tahun 1981 tentang Kitab UndangUndang Hukum Pidana yang berbunyi, "bahwa negara Republik Indonesia adalah negara hukum berdasarkan Pancasila dan Undang-Undang Dasar 1945 yang menjunjung tinggi hak asasi manusia serta yang menjamin segala warga Negara bersamaan kedudukannya di dalam hukum dan pemerintahan dan wajib menjunjung hukum dan pemerintah itu dengan tidak ada kecualinya". Sudah jelas para penegak hukum diberikan kewenangan penegakan hukum dengan selalu menjunjung tinggi hak asasi manusia.

\section{Penutup}

Pertama, apakah pemisahan perkara (splitsing) bertentangan dengan asas Contante Justitie? Jawabannya adalah pemisahan perkara (splitsing) bertentangan dengan Asas Contante Justitie, proses pemeriksaan perkara pidana secara splitsing menimbulkan proses yang berbelit-belit, dimana Terdakwa harus datang ke pengadilan sebagai 2 (dua) status sekaligus, yaitu sebagai Terdakwa dan Saksi. Saat pemeriksaan saksi di Pengadilan menjadi sulit dan membingungkan karena Tersangka yang kemudian dijadikan saksi.

Pasal 141 KUHAP sudah mengatur penyederhanaan perkara pidana yang dilakukan lebih dari satu orang tersangka atau terdakwa dengan melakukan penggabungan perkara. Penggabungan perkara adalah wujud dari peradilan yang cepat, sederhana dan biaya ringan serta wujud dari penghargaan kepada hak asasi manusia. 
Kedua, apakah pemisahan perkara (splitsing) bertentangan dengan asas non self-incrimination? Jawabannya pemisahan perkara (splitsing) memiliki resiko tinggi melanggar asas non self-incrimination. Ketika perkara diperiksa secara terpisah maka Terdakwa dapat dijadikan saksi untuk Terdakwa lainnya, sehingga terdakwa dapat diperiksa sebagai saksi dan memberikan kesaksian dibawah sumpah. Hal ini memaksa Terdakwa untuk menceritakan yang sebenarnya, karena ada sanksi pidana penjara paling lama 9 (sembilan) tahun jika saksi memberikan keterangan palsu. Sama saja dia dipaksa untuk memberikan kesaksian perbuatan pidana yang diduga dilakukan oleh dirinya sendiri serta untuk memberatkan dirinya sendiri.

Hal di atas bertentangan dengan Article 14 paragraph 3 (g) International Covenant on Civil and Political Rights/ ICCPR yang berbunyi Not to be compelled to testify against himself or to confess guilt (Tidak dipaksa untuk bersaksi melawan dirinya sendiri atau mengakui kesalahan). KUHAP sendiri tidak memberikan beban pembuktian kepada tersangka atau terdakwa, terdakwa tidak dipaksa untuk memberikan keterangan dibawah sumpah, ketika terdakwa tidak menjawab pun diperbolehkan dalam KUHAP.

Kekurangan lain dari saksi tersebut adalah saksi akan beresiko memberikan kesaksian palsu walaupun sudah disumpah, dengan tujuan saksi / terdakwa mendapatkan hukuman yang lebih rendah dari pada Terdakwa / saksi lainnya yang akhirnya mereka saling menjatuhkan. Sehingga konfrontir kesaksian saat dipersidangan menjadi tidak efektif dan pencarian kebenaran materiil menjadi tidak sempurna. Maka Biaya yang dikeluarkan tidak sebanding dengan kualitas proses dan hasil akhir persidangan. Hal tersebut bertentangan dengan asas peradilan cepat, sederhana dan biaya ringan.

Penuntut umum harus berhati-hati dalam melakukan pemisahan perkara (splitsing), tidak dibenarkan jika tujuannya hanya memunculkan saksi terhadap suatu tindak pidana. Penggabungan perkara dianjurkan dalam KUHAP, pembuat KUHAP merumuskan ketentuan penggabungan perkara pasti ada maksud dan tujuannya, tidak lain untuk melahirkan sistem peradilan pidana yang cepat, sederhana dan biaya ringan (asas contante justitie) serta untuk memberikan penghargaan 
terhadap Hak Asasi Manusia. Karena jika dilakukan penggabungan perkara terhadap perkara yang dilakukan lebih dari satu, para terdakwa tidak dapat dipaksakan untuk saling memberikan kesaksian sehingga proses persidangan tidak bertentangan dengan asas non self-incrimination.

Saksi mahkota perlu diatur secara tegas dan harus dirumuskan dalam pembaharuan hukum pidana, perlu adanya kebijakan formulasi mengenai saksi mahkota sehingga penerapan saksi mahkota tidak bertentangan dengan peraturan perundang-undangan dan asas-asas yang ada.

Memunculkan saksi dari dakwaan pemecahan perkara yang dimana dia juga sebagai terdakwa sama sekali berbeda dari arti dan tujuan saksi mahkota (kroongetuige). Saksi Mahkota perlu dilindungi keberadaannya, tetapi tidak semua tersangka atau terdakwa bisa dijadikan saksi mahkota dengan seenaknya.
Perlu syarat-syarat seorang tersangka atau terdakwa dijadikan saksi, penulis membuat minimal kebijakan formulasi sebagai berikut :

1. Yang bersangkutan (tersangka/ terdakwa) bukan pelaku utama;

2. Yang bersangkutan (tersangka/ terdakwa) berkomitmen dengan itikad baik akan membantu proses pemeriksaan pidana;

3. Yang bersangkutan (tersangka/ terdakwa) berprilaku baik dan kooperatif;

4. Yang bersangkutan (tersangka/ terdakwa) dilindungi keselamatan dan keamanannya;

5. Yang bersangkutan (tersangka/ terdakwa) diberikan reward ketika menjadi saksi mahkota yang baik dan keterangannya benar, misal dikurangi hukumannya bahkan dapat dibebaskan dari sanksi pidana atau mengganti hukuman non penal. 


\section{DAFTAR PUSTAKA}

\section{A. Buku}

Ali, M. Hatta, Peradilan Sederhana cepat \&Biaya Ringan Menuju Keadlian Restoratif (Bandung: PT. Alumni, 2012).

Burhan Ashofa, Metode Penelitian Hukum, Cetakan pertama (Jakarta: PT Rineka Cipta, 1996).

Atmasasmita, Romli, Sistem Peradilan Pidana Kontemporer (Jakarta: Kencana Prenada Media Group, Jakarta).

Fuady Munir, Hak Asasi Tersangka Pidana (Jakarta: Prenada Media Group, 2015).

Hamzah, Andi, Hukum Acara Pidana Indonesia, (Jakarta: Sinar Grafiaka, 2013).

Harahap, M. Yahya, Pembahasan Permasalahan dan Penerapan KUHAP, Pemeriksaan Sidang Pengadilan, Banding, Kasasi dan Peninjauan Kembali, Edisi II (Jakarta: Sinar Grafika, 2000).

Hartono, Sunaryati, Penelitian Hukum di Indonesia pada Akhir Abad ke-20, Cetakan pertama (Bandung: Penerbit alumni, 1994).

Hiariej, Eddy O.S., Prinsip-Prinsip Hukum Pidana (Yogyakarta: Cahaya Atma Pustaka, 2014).

Marzuki, Peter Mahmud, Penelitian Hukum Edisi Revisi, Cetakan kedua belas, ( Jakarta: Pranadamedia Group, 2016).

M. Ramli, Ahmad, dkk, Menuju Kepastian Hukum di Bidang Informasi dan Transaksi Eletronik (Jakarta: Departemen Komunikasi dan Informatika Republik Indonesia, 2006).

Mulyadi, Lilik, Hukum Acara Pidana:Normatif, Teoritis, Praktik, dan Permasalahannya (Bandung: PT. Alumni, 2007).

Soekanto, Soerjono dan Sri Mamudji, Penelitian Hukum Normatif Tinjauan Singkatan, Cetakan Ketujuh (Jakarta: PT. Raja Grafindo Persada, 2003).

Suratman dan Philips Dillah, Metode Penelitian Hukum,Cetakan Ketiga (Bandung: ALFABETA, 2015).

Sutarto, Suryono, Hukum Acara Pidana, Jilid 1, (Semarang: Badan Penerbit Undip, 1991).

Umar, Dzulkifli dan Usman Handoyo, Kamus Hukum (Jakarta: Quantum Media Press, 2010).

B. Jurnal

Ignatius A. Tiolong, Veibe V. Sumilat, Harold Anis, Wewenang Pemecahan Perkara (splitsing) Oleh Penuntut Umum Menurut Pasal 142 Undang-Undang Nomor 8 Tahun 1981, Lex Crimen Vol. VII/No. 6/Ags/2018. 
Sitti Nurhayati Syamsuningsih, Perlindungan Hukum Terhadap Saksi Mahkota Dalam Perkara Tindak Pidana Korupsi, e Jurnal Katalogis, Volume 4 Nomor 7, 2016.

\section{Makalah}

Igusti Ayu Aditya Wati bekara berjudul, Pemecahan Perkara (Splitsing) Dalam Pra Penuntutan, (Bagian Hukum Administrasi Negara Fakultas Hukum Universitas Udayana), hlm. 5 https://ojs.unud.ac.id/index.php/Kerthanegara/article/view/ $\underline{19000}$, diakses 5 November 2019

\section{Peraturan Perundang-undangan :}

Undang-Undang Republik Indonesia Nomor 12 Tahun 2005 Tentang Pengesahan International Covenant On Civil And Political Rights (Kovenan Internasional Tentang Hak-Hak Sipil dan Politik)

Undang-Undang Republik Indonesia Nomor 48 Tahun 2009 tentang Kekuasaan Kehakiman

Undang-Undang Republik Indonesia Nomor 8 Tahun 1981 tentang Kitab Undang-Undang Hukum Acara Pidana (KUHAP)

Undang-Undang Republik Indonesia Nomor 1 Tahun 1946 tentang Kitab Undang-Undang Hukum Pidana (KUHP)

Surat Edaran Kejaksaan Agung Republik Indonesia No. B-69/E/02/1997

\section{E. Putusan Pengadilan :}

Putusan Mahkamah Agung Nomor 1986 K/Pid/1989 tanggal 21 Maret 1990

Putusan Mahkamah Agung Nomor 1986K/Pid/1 989 tanggal 2 Maret 1990

Yurisprudensi Mahkamah Agung Nomor 1174 K/Pid/1994 tanggal 3 Mei 1995 jo No. 1592 K/Pid/1994 tanggal 3 Mei 1995

Putusan Mahkamah Agung Nomor 2437 K/Pid.Sus/2011

Putusan Pengadilan Negeri Kota Agung Nomor 58/Pid.B/2014/PN.KOT

F. Internet

Sofia Hasanah, Pemisahan Berkas Perkara Pidana (Splitsing), http://www.hukumonline.com //klinik/detail/It588275023a37c/pemisahanberkasperkara-pidana-isplitsing-i, diakses 23 September 2019.

Ilman Hadi, "Definisi Saksi Mahkota, https://www.hukumonline.com/klinik/detail/ It4fbae50accb01/saksi-mahkota/, diakses 11 September 2019. 


\section{BIODATA PENULIS}

Elwindhi Febrian, S.Sn., S.H. lahir di Bantul, lulus pendidikan Strata 1 di Jurusan Musik Institut Seni Indonesia Yogyakarta dengan minat utama musik pop-jazz (2009-2014), lulus pendidikan Strata 1 IImu Hukum Fakultas IImu Hukum Universitas Islam Indonesia dengan konsentrasi Hukum Pidana (2010-2015), sedang menempuh pendidikan Strata 2 Program Magister Hukum Universitas Islam Indonesia dengan bidang kajian umum hukum pidana (2017sekarang). Berprofesi sebagai Advokat / Pengacara, mulai berkarir menjadi Advokat Magang di Rumah Bantuan Hukum Yayasan Afta (2014-2016), Pembela Umum Rumah Bantuan Hukum Yayasan Afta (2016-2017), Kepala Devisi Penanganan Perkara Rumah Bantuan Hukum Yayasan Afta (2017-2018), Ketua Yayasan Aksa Bumi / Lembaga Bantuan Hukum Aksa Bumi (2018-Sekarang). 